POLISH POLITICAL SCIENCE

VOL XLI 2012

PL ISSN 0208-7375

\title{
PHILOSOPHY AND POLITICS IN THE CONTEMPORARY AGE
}

\author{
by Marek Szulakiewicz
}

\begin{abstract}
Political wisdom, judgement or genius do not stem from the spirit of science and is not the upshot of theoretical generalizations or learning. There is of course "political science" and "political philosophy" but politicians can properly act without them because it is neither the discovery of laws or generalizations in the field of politics nor "knowledge about political things" but "political sense" that is crucial for his actions. As Isaiah Berlin put it years ago: "What makes statesmen, like drivers of cars, successful is that they do not think in general terms - that is, they do not primarily ask themselves in what respect a given situation is like or unlike other situations in the long course of human history (which is what historical sociologists, or theologians in historical clothing, such as Vico or Toynbee, are fond of doing). Their merit is that they grasp the unique combination of characteristics that constitute this particular situation this and no other. What they are said to be able to do is to understand the character of particular movement, of a particular individual, of a unique state of affairs, of unique atmosphere, of some particular combination of economic, political, personal factors; and we do not readily suppose that
\end{abstract}


this capacity can literally be taught"1. Therefore politics is not a quest for "general terms" or general features of political phenomena but a direct and individual insight into concrete reality. Being a politician takes not learning but talent, not expertise but intuition, not knowledge but sense; it takes looking not at general but the particular dimension of human actions. Politicians can be taunted for their posture as Napoleon, they can be uneducated as farmer George Washington or act against morality as Cardinal Richelieu but frankly speaking all these vices are unimportant in the political realm.

Since the pragmatic nature of politics is a reason of contradiction between philosopher and politician. In the history of philosophy the wisdom of a philosopher was contrasted with the intuition of a politician. Greeks underlined that the politician has got some peculiar trait which consists of the ability of unveiling communitarian dimension of the world which is hidden from philosophers. Where a philosopher transcends the world, there a politician acts in the inter-subjective public realm, in the world shared with others. That was considered as an advantage for the a politician over the philosopher since political opinions often are more embedded in culture than theoretical truths of philosophy. But even though a philosopher searches for truth via theoretical reflection and a politician relies upon opinion or rumour, these two approaches towards reality are not opposed to each other. It is rather that they can meet in the space of truth. Let me remind the dilemma introduced in Plato's Gorgias ${ }^{2}$. The question posed by Plato - What is the best way of life? Spending it as a rhetorician who addresses the public on the forum or as a philosopher devoted to searching for truth? - it is answered by the possibility of conducting political discourse in philosophical terms and the common quest for truth. Existing conflict between philosophical truth and the judging intuition of a politician stem not from the adventitious circumstances due to which a politician does not follow a philosopher's advice but from the

1 I. Berlin, Osąd polityczny, in: idem, Zmyst rzeczywistości. Studia z historii idei, trans. M. Filipczuk, Poznań 2002, p. 75.

2 Platon, Gorgias. Menon, trans. P. Siwek, Warszawa 1991, p. 93. 
fact that a politician cannot employ his political intuition or, in other words, from the fact that he is not a good politician. Political genius consist in avoiding pitfalls of linear thinking in which moral and practical ought is derived from speculative is and historical was.

But quite often politics were exercised under the guise of philosophy. In that case it was a philosopher who criticised social structures (as Socrates), tried to seize power because he "knows better" (as Plato), or advised others (as Aristotle). Nevertheless, a philosopher does not substitute for a politician and his political judgement and genius. There are so called learned philosophers who either try to critically judge existing ideologies or have their own utopian ideologies and then try to form the world in accordance with these ideal models. But particularly because they prefer theory and ideology to political practice and pragmatism, they cannot be called real politicians.

Therefore a philosopher and a politician are not a perfect match. What is the reason for this situation? It is a philosopher's peculiar inclination towards violence. Such propensity is uncommon for real politicians ${ }^{3}$. This antagonism between philosophy and politics is especially visible in the contemporary world because of a change in the way of conducting political discourse and because there is a priority of politics to philosophy.

\section{PHILOSOPHER AND POLITICIAN - A BAD MATCH}

During the twentieth century there was an attempt to get rid of differencies between philosophy and politics, to blur the distinction between philosophical truth and political intuition, to bring the philosopher closer to the politician. There were different ways of doing this. One of them was an attempt to realize philosophy in a political manner. In the twentieth century a plethora of philosophers - following Plato - served in the courts of tyrants. Those philosophers were in favour of unification of spirit and political power, in favour of unification of governors and philosophers,

3 Ch. Delacampagne, Filozof i tyran, trans. K. Łukowicz, Kraków 2003, p. 191. 
action and thought. These attempts were based on a desire to establish a new political and social order which firstly was invented by philosophers and which would then be realized by politicians or philosophers under the guise of politicians. It means that in the twentieth century the philosophical world of ideas was identified with the real world of politics. In the past a philosopher was much more connected with the world of Forms than with the real world of politics. Nowadays ideas descend from the world of Forms and this move down is very precarious for philosophy as well as for politics. In the age of Enlightenment Immanuel Kant was aware of this danger. As he noticed in the Secret Article for Perpetual Peace: "That kings should philosophize or philosophers become kings is not to be expected. Nor is it to be wished, since the possession of power inevitably corrupts the untrammeled judgement of reason"4. For philosophy this connection with politics means that philosophy becomes a "thinking of this world" and looses its superior position to politics. In other words, it means that philosophy evolves towards indoctrination and propaganda. In turn for politics this connection with philosophy means that politics confuses its own nature. It means that there occurs a conjecture that politicians can truly love wisdom. The twentieth century by blurring the last marks of separateness of philosophical truth and rhetorical opinion creates a dangerous idea of identity of those two spheres. Contemporary world is then both against the idea of Karl Mannheim that reason should be independent of politics and in contradiction with the idea of Henryk Elzenberg that the best situation for philosophy is "when public is not concerned with philosophy".

One can think that such a connection between philosophy and politics is unnatural because it is not difficult to prove that truth and politics are not in accordance with each other. Moreover, often a lie or manipulation is considered as a fruitful method in politics, much better than truth. It is as well obvious that philosophical ideas played a crucial role in politics over a span of ages, especially in the twentieth century. Both great political projects of organizing social order such as liberalism, democracy,

4 I. Kant, Do wiecznego pokoju. Projekt filozoficzny, trans. M. Żelazny, Toruń 1995, p. 77. 
communism, or fascism and projects of smaller reforms stem from the theoretical consideration of philosophers. That is why philosophers and political scientists are so devoted to searching for some theory explaining this relation between philosophy and politics. Such an explanation seems to be a key for the understanding of the twentieth century which was meant to be the epoch of unity of thinking and action. But the question still remains: Where in the heterogeneous culture of twentieth century one should look for the basis for such theory?

Undoubtedly, to understand the relation between philosophy and politics one must have some understanding of the nature of philosophy and politics. During past ages such understanding was provided by philosophers, thinkers, and politicians. Politics in ancient Greece and in later epochs was regarded as this peculiar sphere where people were considering and searching for the common good. According to Leo Strauss, "All political action aims at either preservation or change. When desiring to preserve, we wish to prevent a change for the worse; when desiring to change, we wish to bring about something better. All political action is then guided by some thought of better or worse" 5 . In both cases politics cannot bracket moral questions about common good and values. To act politically one must by definition base one's action on some discrimination between better and worse, good and evil. The fundamental premise of politics is some consciousness of the good and all political plans must be based on such consciousness. But the problem is with consciousness itself. What should be the reason for or against particular political action? What does the distinction between the better which one should aim at and the worse which one should avoid stem from? Obviously, past philosophy answered that public opinion, emotions, or desires cannot be such reasons. It should be sole knowledge of the good. Only philosophy which transcends empirical reality can provide us with such knowledge. Only philosophy can give a politician confidence that his projects and actions are not motivated by egoistic desire to seize power or realize his particular ends and that these plans are not relative to public opinion and expecta-

\footnotetext{
${ }^{5}$ L. Strauss, Czym jest filozofia polityki, in: idem, Sokratejskie pytanie. Eseje wybrane, trans. P. Maciejko, Warszawa 1998, p. 61.
} 
tions of the mob. Thanks to this connection with philosophy a politician can distinguish between what ought to be done and what can be done on the basis of public expectations. As put by Leo Strauss, political thought is insensitive for the distinction between truth and opinion ${ }^{6}$. This distinction takes political philosophy. Hannah Arendt argues that political philosophy has occurred when man turned his back on politics and looked at the realm of Forms and then came back to politics imposing on politics philosophical criteria? .

The necessity of philosophy for politics comes from a need to find some new sense in political actions and to show that one cannot derive practical ought from empirical or theoretical is. But in this necessity there is gargantuan danger often underlined by many philosophers and even politicians. This danger consists in a seduction of politics by philosophy. Offering an a priori meaning for political actions, philosophy can impose such a world view which does not exist empirically but which ought to exist. The problem with that does not consist in expectation that the politician should realize such an ideal world; it does not consist in fact that such an ideal worlds could not be realized and that such attempts always ended in failure either. The problem consists in interpreting and judging the existing world in the light of these ideal standards and models of political order. In that utopian project there were roots of ideological and totalitarian regimes common for twentieth century societies.

The situation and relation between philosophy and politics which have been presented till now belongs to out past culture. The question is: How philosophy has changed since the twentieth century and what changes have occurred in the field of politics that allow us to talk about revaluation of traditional spheres of our culture?

\footnotetext{
6 Ibidem, p. 64.

7 H. Arendt, Między czasem minionym a przyszłym. Osiem ćwiczeń z myli politycznej, trans. M. Godyń, Warszawa 1994, p. 29.
} 


\section{PHILOSOPHY IN THE CONTEMPORARY WORLD - THOUGHT AT TIME'S SERVICE}

The nineteenth century was not the age of theory and is often called "the century of modern scientism" during which one of the most popular watchwords was laissez faire and during which the measure of the value of theory was the possibility of its practical implementation. But philosophy in the nineteenth century was still the theory of reality which was offering a universal world view, hierarchy of values and which was underlining the assertion that life is going on within a framework of established social order. Albeit philosophical thinking freed itself from Hegelian speculations, by the end of the nineteenth century the dissonance between philosophy and reality (world, culture, daily life) was visible. The gap between philosophical dreams or constructions and life reality was a testament at the end of nineteenth century whereas the attempt to bridge this gap was a task for the new twentieth century.

Nonetheless in the field of philosophy the twentieth century did not start optimistically it was not without hope that philosophy can play an important role in culture later on. At the outset of that century there was a warning heard in every single philosophical stream but which was articulated in the strongest way by Lev Shestov who underlined the danger of practice undertaken by philosophy at that time which consisted in obscuring the truth instead of displaying it. Because of the triumph of positivism, Marxism growing in strength, and the beginning of phenomenology philosophy had to justify its own necessity and even existence. That was the first culturally important crisis in its identity. And at that moment thinkers made a huge effort to show that philosophy can be important, needed and wanted or, to put it another way, to proof that philosophy can undergo such modification that will become crucial in our culture.

This diagnosis of impracticality of philosophy was nothing new. Even the first fully-fledged philosopher Socrates was criticized for converting young Athenians into useless citizens and diverting their thinking from practical and serious problems (Gorgias). What was new about it during the twentieth century, was seeing this impracticality as a philosophical problem. At the outset of the twentieth century thinkers realized that it is 
a philosophical issue and that there should not be reasons for feeling shame or excusing the fact that "only philosophy did not beget practical results". Awaking philosophy to fruitful life - that was the task for the twentieth century; that was the testament of passing epoch and the vow made by all important philosophical streams in the first half of the twentieth century. Some philosophical streams were doing it in an open way (as Marxism), some under the disguise of throwing away everything that was impractical in philosophy (as neo-positivism), some were changing the meaning of philosophy so thoroughly that they blurred the difference between cognition and action (as Bergson's theory of intuition), some dreamed about alluring philosophy (as pragmatism), some were looking for some new starting point of philosophy (as in the case of Edmund Husserl). All those attempts stemmed from the existing consciousness of the opposition between philosophy and life and from the endeavour to overcome this opposition. Only Neo-Kantianism showed resistance with regard to such attempts but - as Hans-Georg Gadamer put it - this stream was destroyed during the First World War.

Over the span of the first half of the twentieth century traditional dependence of concrete life on philosophy was changed and replaced by the opposite direction of dependence - from that time philosophy has been dependent on concrete life. But this process could be possible at a price by changing the focus and scope of philosophy. At the turn of century one of the peculiar features of philosophy was the gradual diverting from the first things, categories, necessity and increasing interest in the phenomenal world, interpretation and relativity. So the philosopher could not be a moral adviser because he himself was of this world, he could not refer to some fundamentals because culture did not need philosophical foundation. In the context of establishing this new field of philosophy it is often underlined that "what is important is neither what we do nor what we ought to do but what happens to us regardless of our will and action"9. Paradoxically, the attempt to include philosophy in the world has closed

\footnotetext{
8 F. Brentano, Über die Zukunft der Philosophie, Leipzig 1929, p. 99.

9 H.-G. Gadamer, Prawda i metoda. Zarys hermeneutyki filozoficznej, trans. B. Baran, Kraków 1993, p. 24.
} 
traditional possibilities for philosophy understood as a quest for the better and has made room for philosophy understood as only simple description of what actually exists. But this situation has had an impact on politics, life, and practice. There is a close connection between making philosophy practical and provoking events which are dangerous for culture, events which degrade culture, reinforce instrumental attitude, and strip politics of philosophical legitimization. The previous role of philosophy in culture consisted of providing human life with additional meaning, giving incentives for searching and transcending reality; on the other hand this role consisted of making the most important distinctions, like those between good and evil, war and peace, true and false, reason and insanity, or knowledge and ignorance. Philosophy of this world cannot play this role. On the contrary, such "live" philosophy itself blurs these distinctions, deconstructs fundamental concepts, and introduces elements of vagueness. Such philosophy devoted to world, culture, practice, perspective of present time maintains that everything can be cancelled, annihilated or discredited from the point of view of different practice or culture.

One can say that where during the nineteenth century theoretical importance of philosophy eliminated historical and subjective dimension of reality or at least made it unimportant, then during the twentieth century practical importance of philosophy seemed to perceive only this dimension. Damages for philosophical thinking caused by the fulfilment of the nineteenth century dream about practical philosophy are enormous. Amongst them one can enumerate locality of importance, rupture with a traditional set of categories and concepts, the feeling of loneliness of man who is striped off robust measures is forced to act but without any concept of the aim of such action. These are only some consequences of the reduction of distance between theory and practice. Philosophy lost "theoretical significance" instead of gaining "practical value". 


\section{CONTEMPORARY POLITICS}

This change also touches contemporary politics. Benedetto Croce presenting a situation in nineteenth century Europe points to the fact that at that time politics was dominated by one word - "freedom". In the nineteenth century what flourished and matured was the "religion of freedom" which meant pluralistic society and constitutional government, democracy and human rights. As a political idea freedom occurred both in the dimension of "humanitarian individualism" and "romantic nationalism". These dimensions were connected with each other by a belief that social and individual problems can be overcome only when stupidity and villainy will be replaced by reason and morality. This belief in the rational foundation of politics and the rationality of political actions was confirmed by the understanding of history as a battleground for two forces: reason and ignorance, progress and reaction. The nineteenth century created the idea of politics as a project for realization which in actual fact is outside empirical reality, outside the world and concrete life of an individual. Politics was somehow added to real life and the world; the political world was regarded as ideal and prior to the empirical one, as a project which ought to be realized.

The twentieth century and contemporary age understand politics differently. First and foremost the traditional conceptual framework stems from Greek philosophy and has collapsed; this conceptual framework was crucial for the linear development of European thought and conceived politics as a rational realm. After this rupture political discourse and action stopped to be carried out in philosophical terms; politics stopped to be moral critics of rulers and regimes. As Otfried Höffe put it, philosophers who want to change the world are in danger of "becoming immature thinkers and amateur politicians, i.e. bad theoreticians and bad practitioners at once"10.

Secondly, politics nowadays is defined by the emergence of the masses and public opinion. This social phenomenon has changed the nature of political legitimization. Since then philosophical legitimization of political actions has become simply out of the question. At the turn of the twenti-

10 O. Höffe, Sprawiedliwość polityczna. Podstawy krytycznej filozofii prawa i państwa, trans. J. Merecki, Kraków 1999. p. 24. 
eth century it was obvious that all political regimes are imperfect and politics is not a battlefield for good and evil but a choice between bigger and lesser evil. To make such a choice one does not need philosophy with its quest for fundamentals and transcendent justifications. It is enough to ask public opinion. Herderian idea of the holiness of people expressed by a watchword "the voice of people is the voice of truth" became the condition for political activity. One's need for justification and legitimization is fulfilled by the universal suffrage. In turn the actions of politician are oriented not towards universality of philosophy but towards public opinion which should be formed properly to obtain legitimization from it. Politicians became experts in forming public opinion by putting aside all uncomfortable topics and issues. Although the source of political legitimization is human and citizen freedom, it is a freedom properly fabricated beforehand. In practice it means that political legitimization has got sheer pragmatic character and is dependent on improving the material standard of life, providing safety and public peace. But such legitimization has nothing in common with justifying political ideas on which political action should be based. According to Niklas Luhmann it means that the political system itself took over the task of ideology. Such justification is connected with the axiological neutrality and lack of common standards of good life. Politics is - as in the twenties Nikolai Berdyaev put it - "ontically empty" and identifies people's will with truth. Therefore it is not striving for common aims and goods but just an art of exercising power which is assessed by criteria of efficiency.

The mass culture caused that politics left its peculiar realm occupied in the nineteenth century and started to regulate most of the spheres of social life. The influence politics has got on different spheres of life is so gargantuan that sometimes even political indifference is treated as just one form of political actions. This situation seems to be an unintended effect of the loss of the role of tradition and philosophy in culture. The undermining of cultural fundamentals takes the politicization of these spheres of life which were previously within the domain of private life. Since tradition and philosophy lost their role in the shaping of social reality public discourse became the only available tool for searching for jus- 
tification and importance. So politics became the last resort for people who could not find an agreement between each other ${ }^{11}$.

These are only a few faces of politics in the twentieth century. Differences between nineteenth century and contemporary political ideas are quite visible. In actual fact the history of political ideas in the twenty first century is to a huge extent the history of a quarrel between, on the one hand, the old tradition of the nineteenth century connected with a belief that it takes solely intellectual and moral potential to overcome all political problems and, on the other, ideas of the twentieth century according to which politics is relative to a given historical moment and daily life. This conflict changes the understanding of politics: it stops being a tool for shaping the world by transforming it or conserving it and starts to be a tool for adaptation to the actual form of the world.

\section{CONCLUSION}

Hannah Arendt, one of the most perspicacious political thinkers of the twentieth century, argued that the crisis of the modern world has got political character. The same age brought rumours that philosophy is dead. Nevertheless, nowadays paths of philosophy and politics are still intermingled and have not yet split. These two spheres of human activity are not indifferent towards each other. On the contrary, we can still talk about some philosophical context of politics albeit understood in different terms. One of the most important philosophers of the twentieth century, Paul Natrop maintained that community cannot be built from the outside but it must grow from within. If we look at contemporary politics and philosophy we will see that both of them recognizes this truth formulated by Natrop. Both politician and philosopher know that their role cannot consist in making heaven on earth. But on the other hand, we can notice that our culture is passing the threshold beyond which the hypothesis of Richard Rorty will proove its value and politics will be prior to philoso-

\footnotetext{
11 S. Macedo, Cnoty liberalne, trans. G. Łuczkiewicz, Kraków 1995, p. 74.
} 
phy ${ }^{12}$. This priority of politics over philosophy means that politics is assessed in terms of efficiency. On the one hand politics does not want philosophy any more, does not have any requirements towards philosophy and treats philosophers as dangerous dreamers; on the other hand philosophy itself resigns from its traditional social role and has accepted the priority of politics. It does not mean of course that politicians do not need "great theories". On the contrary, we can observe that such a need is getting bigger nowadays, for example in the search for unity in Europe. From this need originate a new task for philosophy: to find some principle of association, some common ground for different people. The general world view can be more attractive than the fragmented one. But postmodern philosophy says "no" for this task and proposes ironic distance towards all world views. It points at the end of all great theories. Philosophy disappoints politicians and political scientists but at the same time gives a warning that because of great theories we can lose this tremendous privilege about which Gadamer spoke: "Europe could and had to learn how to live with different people".

12 R. Rorty, Pierwszeństwo demokracji wobec filozofii, [in:] idem, Obiektywność, relatywizm, prawda. Pisma filozoficzne, t. I, trans. J. Margański, Warszawa 1999, p. 261 and next. 